\title{
PENGARUH EVALUASI KURIKULUM DALAM PENINGKATAN PRESTASI \\ BELAJAR PESERTA DIDIK
}

\author{
Shofil Fuad Madani \\ Ririn Maulidiyah \\ Gading Satya Pambayun \\ Agung Prastiyo \\ Program Studi Administrasi Pendidikan, FIA, Universitas Brawijaya \\ Jl. Veteran, Ketawanggede, Kec. Lowokwaru, Malang
}

\begin{abstract}
ABSTRAK
Penulisan artikel ini bertujuan untuk mendeskripsikan pengaruh evaluasi kurikulum dalam peningkatan prestasi belajar peserta didik. Artikel ini merupakan karya ilmiah yang dibuat dengan menggunakan metode studi pustaka yang mengkaji buku-buku, literatur-literatur, jurnal-jurnal penelitian yang berkaitan dengan topik artikel yang penulis tulis, metode pengumpulan data yang digunakan yaitu studi pustaka. Hasil penelitian menunjukkan bahwa peningkatan prestasi belajar peserta didik sangat dipengaruhi oleh keefektifan evaluasi kurikulum.
\end{abstract}

Kata Kunci: Evaluasi Kurikulum, Prestasi Belajar, Siswa

\begin{abstract}
Writing this article aims to describe the effect of curriculum evaluation in improving student achievement. This paper is a scientific work made using a literary approach that examines books, literatures, research journals related to the topic of the article that the author wrote, the data collection method used is literature study. The results of the study indicate that the increase in student achievement is strongly influenced by the effectiveness of curriculum evaluation.
\end{abstract}

Keywords: Curriculum Evaluation, Learning Achievement, Students 


\section{PENDAHULUAN}

Evaluasi merupakan bagian dari sistem manajemen yaitu perencanaan, organisasi, pelaksanaan, monitoring dan evaluasi. Kurikulum juga dirancang dari tahap perencanaan, organisasi kemudian pelaksanaan dan akhirnya monitoring dan evaluasi. Tanpa evaluasi, maka tidak akan mengetahui bagaimana kondisi kurikulum tersebut dalam rancangan, pelaksanaan serta hasilnya.

Peningkatan kualitas pendidikan harus dilakukan secara terus menerus dan berkesinambungan. Hal ini bisa difahami karena kualitas pendidikan selalu berflutuaksi. Saat ini berkualitas saat lain belum tentu berkualitas, karena tuntutan masyarakat, perkembangan ilmu dan teknologi serta seni berubah seiring dengan perubahan waktu. Menurut Quisumbing (2003), kualitas pendidikan adalah proses yang dinamik, tidak statis dan bukan berupa produk akhir. Tingkat kualitas ditentukan oleh tuntutan masyarakat dan perkembangan ilmu pengetahuan dan teknologi serta seni. Kualitas pendidikan dipengaruhi oleh banyak faktor, antara lain: kualitas peserta didik, kualitas pendidik, kualitas lingkungan belajar, kualitas kurikulum, dan kualitas proses pembelajaran. Oleh karena itu, sudah sewajarnyalah bila dalam rangka meningkatkan kualitas pendidikan melalui peningkatan kualitas kurikulum maka perlu dilakukan evaluasi kurikulum.

Evaluasi kurikulum memegang peranan penting dalam proses pendidikan dengan tujuan mengetahui hingga manakah siswa mencapai kemajuan ke arah tujuan yang telah ditentukan. Namun dalam hal evaluasi kurikulum harus dilaksanakan dengan sistematis yang sesuai dengan konsep dasar evaluasi kurikulum, sehingga hasil evaluasi kurikulum sesuai dengan kebutuhan dan kemampuan pelaku-pelaku dunia pendidikan dan masyarakat secara umum.

Evaluasi Kurikulum dilaksanakan secara komprehensif agar mencapai tujuan yang maksimal. Dengan pemahaman terhadap dasar-dasar evaluasi kurikulum dapat membantu para pengembang kurikulum untuk merancang evaluasi kurikulum yang sesuai kajian-kajian teoritis yang relevan. Kegiatan mengeksplorasi dasar-dasar pelaksanaan evaluasi dalam kurikulum sebagai bagian yang penting dan saling berkaitan antara satu dengan yang lainnya. Hal ini tentunya harus dipertimbangkan dalam perencanaan dan penyusunan evaluasi kurikulum, yaitu berkaitan dengan sejarah perkembangan evaluasi kurikulum, peran evaluasi kurikulum, tujuan evaluasi kurikulum, pendekatan dalam evaluasi kurikulum, dan model-model evaluasi kurikulum. 


\section{METODE}

Di dalam melakukan analisis terkait persoalan artikel, penulis menggunakan metode studi pustaka. Penulis menggunakan beberapa sumber pustaka yang dapat dijadikan referensi dalam menganalisis pengaruh evaluasi kurikulum dalam peningkatan prestasi belajar peserta didik.

\section{HASIL DAN PEMBAHASAN}

\section{Pengertian Evaluasi Kurikulum}

Pengertian evaluasi menurut joint committee, 1981 ialah penelitian yang sistematik atau yang teratur tentang manfaat atau guna beberapa obyek. Purwanto dan Atwi Suparman (1999), mendefinisikan evaluasi adalah proses penerapan prosedur ilmiah untuk mengumpulkan data yang valid dan reliabel untuk membuat keputusan tentang suatu program. Rutman and Mowbray (1983) mendefinisikan evaluasi adalah penggunaan metode ilmiah untuk menilai implementasi dan outcomes suatu program yang berguna untuk proses membuat keputusan. Chelimsky

(1989) mendefinisikan evaluasi adalah suatu metode penelitian yang sistematis untuk menilai rancangan, implementasi dan efektivitas suatu program. Dari definisi evaluasi di atas dapat ditarik kesimpulan bahwa evaluasi adalah penerapan prosedur ilmiah yang sistematis untuk menilai rancangan, implementasi dan efektifitas suatu program. Sedangkan pengertian kurikulum adalah :

a. Kurikulum adalah seperangkat rencana dan pengaturan mengenai tujuan, isi, dan bahan pelajaran serta cara yang digunakan sebagai pedoman penyelenggaraan kegiatan pembelajaran untuk mencapai tujuan pendidikan tertentu (Pasal 1 Butir 19 Undang-Undang Nomor 20 Tahun 2003 tentang Sistem Pendidikan Nasional);

b. Seperangkat rencana dan pengaturan mengenai isi dan bahan pembelajaran serta metode yang digunakan sebagai pedoman menyelenggarakan kegiatan pembelajaran (Keputusan Menteri Kesehatan Nomor: 725/Menkes/SK/V/2003 tentang Pedoman Penyelenggaraan Pelatihan di bidang Kesehatan.).

c. Kurikulum pendidikan tinggi adalah seperangkat rencana dan pengaturan mengenai isi maupun bahan kajian dan pelajaran serta cara penyampaian dan penilaiannya yang digunakan sebagai pedoman penyelenggaraan kegiatan belajarmengajar di perguruan tinggi (Pasal 1 Butir 6 Kepmendiknas No. 232/U/2000 tentang Pedoman 
Penyusunan Kurikulum Pendidikan Tinggi dan Penilaian Hasil Belajar Mahasiswa);

d. Menurut Grayson (1978), kurikulum adalah suatu perencanaan untuk mendapatkan keluaran (outcomes) yang diharapkan dari suatu pembelajaran. Perencanaan tersebut disusun secara terstruktur untuk suatu bidang studi, sehingga memberikan pedoman dan instruksi untuk mengembangkan strategi pembelajaran (Materi di dalam kurikulum harus diorganisasikan dengan baik agar sasaran (goals) dan tujuan (objectives) pendidikan yang telah ditetapkan dapat tercapai;

e. Menurut Harsono (2005), kurikulum merupakan gagasan pendidikan yang diekpresikan dalam praktik. Dalam bahasa latin, kurikulum berarti track atau jalur pacu. Saat ini definisi kurikulum semakin berkembang, sehingga yang dimaksud kurikulum tidak hanya gagasan pendidikan tetapi juga termasuk seluruh program pembelajaran yang terencana dari suatu institusi pendidikan.
Keterkaitan Evaluasi Kurikulum dalam Peningkatan Prestasi Belajar Peserta Didik
Evaluasi
kurikulum
dapat menyajikan informasi mengenai kesesuaian, efektifitas dan efisiensi kurikulum tersebut terhadap tujuan yang ingin dicapai dan penggunaan sumber daya, yang mana informasi ini sangat berguna sebagai bahan pembuat keputusan apakah kurikulum tersebut masih dijalankan tetapi perlu revisi atau kurikulum tersebut harus diganti dengan kurikulum yang baru. Evaluasi kurikulum juga penting dilakukan dalam rangka penyesuaian dengan perkembangan ilmu pengetahuan, kemajuan teknologi dan kebutuhan pasar yang berubah.

Evaluasi kurikulum dapat menyajikan bahan informasi mengenai area-area kelemahan kurikulum sehingga dari hasil evaluasi dapat dilakukan proses perbaikan menuju yang lebih baik. Evaluasi ini dikenal dengan evaluasi formatif. Evaluasi ini biasanya dilakukan waktu proses berjalan. Evaluasi kurikulum juga dapat menilai kebaikan kurikulum apakah kurikulum tersebut masih tetap dilaksanakan atau tidak, yang dikenal evaluasi sumatif. Setiap pendidik tentu sangat mengharapkan anak didiknya agar berprestasi seoptimal mungkin baik pada jalur akademik maupun 
nonakademi. Prestasi memiliki pengertian yang sangat luas. Apabila peserta didik dapat mencapai cita-cita atau minimal dapat menyelesaikan tugas dari guru maupun orang lain maka ia disebut berprestasi. Prestasi Belajar di bidang pendidikan adalah hasil dari pengukuran terhadap peserta didik yang meliputi faktor kognitif, afektif dan psikomotor setelah mengikuti proses pembelajaran yang diukur dengan menggunakan instrumen tes atau instrumen yang relevan. Jadi, prestasi belajar adalah hasil pengukuran dari penilaian usaha belajar yang dinyatakan dalam bentuk simbol, huruf maupun kalimat yang menceritakan hasil yang sudah dicapai oleh setiap anak pada periode tertentu. Prestasi Belajar merupakan hasil dari pengukuran terhadap peserta didik yang meliputi faktor kognitif, afektif dan psikomotor setelah mengikuti proses pembelajaran yang diukur dengan menggunakan instrumen tes yang relevan.

\section{Upaya untuk Memaksimalkan Prestasi}

\section{Belajar Peserta Didik}

Upaya meningkatkan prestasi belajar peserta didik memang tidak mudah. Hal ini mengingat mood dari seorang peserta didik akan cepat sekali berubah. Itu sebabnya diperlukan kreatifitas dari orang tua atau guru. Berikut ini upaya mengenai cara meningkatkan prestasi belajar anak yang dapat diterapkan sehari-hari antara lain:

1. Cara belajar yang beragam. Cara meningkatkan prestasi belajar anak selanjutnya adalah menerapkan metode belajar yang beragam. Dalam mengajar anak harus ada metode yang diterapkan. Dengan adanya metode belajar yang beragam membuat anak merasa bahwa belajar merupakan hal yang sangat menyenangkan. Ini baik untuk menghindari rasa tertekan yang dirasakan anak dalam belajar.

2. Menerapkan metode belajar dan bermain. Fakta menyatakan bahwa seorang peserta didik sangat senang sekali untuk bermain dan belajar. Namun hampir semua waktu dimasa anak-anak dihabiskan untuk bermain bersama dengan temantemannya. Maka langkah terpenting yang harus dilakukan oleh orang tua atau guru adalah mengajak anak untuk bermain sambil belajar. Cara belajar yang baik ini telah lama diterapkan untuk meningkatkan prestasi belajar peserta didik. Jadi saat pelajaran sudah dimulai ajak juga anak untuk bermain jika saat itu ia ingin bermain. Para guru dan 
orang tua tentu tahu cara metode penerapan bermain dan belajar ini dengan baik.

3. Memberikan solusi yang tepat. Meningkatkan prestasi belajar peserta didik selanjutnya adalah memberikan solusi. Terkadang peserta didik merasa kesulitan untuk melakukan tugas belajarnya. Disini pendidik tidak perlu memaksanya untuk menemukan solusi namun berikanlah solusi. Bisa jadi solusi yang pendidik berikan ini menjadi pemicunya untuk semangat belajar dan berprestasi disekolah. Karena menyadari bahwa orang tuanya selalu memberikan yang terbaik untuk dirinya.

4. Jujur. Cara meningkatkan prestasi belajar peserta didik selanjuntya adalah jujur. Disini baik para pengajar maupun anak harus jujur tentang apa yang mereka rasakan. Anak-anak pada dasarnya memang selalu berkata jujur. Jadi ajak peserta didik untuk berdiskusi atau bercerita perihal rasa belajar yang dirasakannya. Dengan ini para pengajar bisa melihat apa saja kendala yang dialami anak saat belajar dan juga apa yang membuatnya termotivasi saat belajar. Dengan itu cobalah lebih banyak lakukan hal-hal yang dapat membuat anak menjadi termotivasi. Setelahnya baru lihat bahwa prestasi belajar anak perlahan meningkat.

5. Menciptakan suasana belajar yang nyaman. Menciptkan suasana belajar memang penting, karena suasana juga ikut mempengaruhi anak dalam menerima pelajaran yang disampaikan. Jika suasana belajar menyenangkan maka akan sangat mudah sekali bagi anak untuk menerima pelajaran yang diberikan.

6. Memberikan pujian atas prestasi peserta didik. Setiap peserta didik senang untuk dipuji begitu mereka mendapatkan prestasi yang meningkat dari sebelumnya. Pujian yang diberikan oleh orang tua menambah semangat anak dalam berprestasi. Namun usahakan juga untuk memberikan pujian yang tulus pada anak. Karena meskipun masih kecil peserta didikjuga dapat membedakan mana pujian tulus dan tidak.

\section{SIMPULAN}

Evaluasi kurikulum adalah kegiatan yang sistematis untuk menilai rancangan, implementasi, produk, dan dampak suatu 
kurikulum. Evaluasi kurikulum memiliki peranan penting dalam dunia pendidikan. Tanpa adanya evaluasi kita tidak akan tahu kelemahan dan kekuatan di dalam perencanaan maupun proses implementasi kurikulum yang telah digunakan. Dan menjadikan hal tersebut sebagai umpan balik oleh pihak-pihak yang berkepentingan, seperti halnya; orang tua, guru, pengembang kurikulum masyarakat, dan lain-lain. Sehingga hal tersebut bisa dijadikan acuan untuk perbaikan dan pengembangan kurikulum yang akan datang sehingga peserta didik mampu mencapi tujuan pendidikan yang telah ditetapkan dengan seefektif mungkin.

\section{REFERENSI}

Hamdi, M. M. (2020). Evaluasi Kurikulum Pendidikan. Intizam, Jurnal Manajemen Pendidikan Islam. 4 (1). 66-75.

Hermana Somantrie (2009). Mengapa

Perlu Evaluasi Kurikulum?.

Jakarta: Puskur

Ismail, Fajri. 2014. Model-Model Evaluasi Kurikulum, Lentera STIKIP-PGRI Bandar Lampung. Vol. 2.

Keputusan Menteri Kesehatan Nomor 725

Tahun 2003 tentang Pedoman
Penyelenggaraan Pelatihan di

Bidang Kesehatan.

Keputusan Menteri Pendidikan Nasional Nomor 232 Tahun 2000 tentang

Pedoman Penyusunan Kurikulum Pendidikan Tinggi dan Penilaian Hasil Belajar Mahasiswa.

Kementrian Pendidikan dan Kebudayaan. 2013. Kurikulum 2013. Jakarta:

Kemendikbud

Muhammad, Ali. 2009. Pengembangan Kurikulum di Sekolah. Bandung: Sinar Baru Algensindo.

Mulyana A. (2020). Prestasi Belajar

Siswa, Pengertian dan Faktor yang Mempengaruhi Prestasi Belajar Siswa.

https://ainamulyana.blogspot.com/2 016/01/prestasi-belajar-siswapengertian-dan.html. Diakses pada 8 Desember 2021.

Sudarsono, S. (2016). Upaya Manajerial Pengembangan Kurikulum Program Unggulan Di Madrasah Aliyah. UIN Sunan Ampel Journal of Islamic Education. 4 (1). 92-115.

Trenggana, I. J. Evaluasi Kurikulum.

Undang-Undang Nomor 20 Tahun 2003 tentang Sistem Pendidikan Nasional. 
Zulharman. (2007). Evaluasi Kurikulum :

Pengertian, Kepentingan dan

Masalah yang Dihadapi.

https://zulharman79.wordpress.com

/2007/08/04 /evaluasi-kurikulum-

pengertian-kepentingan-dan-

masalah-yang-dihadapi. Diakses

pada 8 Desember 2021. 